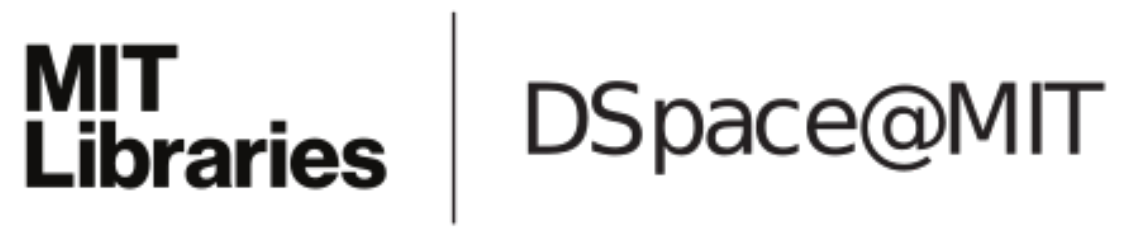

\author{
MIT Open Access Articles
}

Not Your Usual "Founders"

The MIT Faculty has made this article openly available. Please share how this access benefits you. Your story matters.

Citation: Maier, Pauline. “Not Your Usual 'Founders'." Reviews in American History 40.4 (2012): 557-565. Web.

As Published: http://dx.doi.org/10.1353/rah.2012.0107

Publisher: Johns Hopkins University Press

Persistent URL: http://hdl.handle.net/1721.1/76800

Version: Author's final manuscript: final author's manuscript post peer review, without publisher's formatting or copy editing

Terms of use: Creative Commons Attribution-Noncommercial-Share Alike 3.0 


\title{
NOT YOUR USUAL “FOUNDERS”
}

\section{Pauline Maier}

\author{
Alfred F. Young, Gary B. Nash, and Ray Raphael, eds. Revolutionary Founders: \\ Rebels, Radicals, and Reformers of the Nation. Alfred A. Knopf; New York, 2011. 452 \\ pp. $\$ 32.50$.
}

Revolutionary Founders is, to my mind, one of the best recent books on the American Revolution, and one that, unlike so many others, could actually be of use in the college classroom. It includes an introduction by the editors, an afterword by Eric Foner, and twenty-two essays, each by a different scholar, focused on an individual (or group of individuals) who played a role in the Revolution and whose story highlights some aspect of the event. The essays are divided into three sections-Revolutions, Wars, and The Promise of the Revolution. That gives the book range: it goes from the organization of resistance to Britain through the war to the impact of the Revolution, particularly of its promise of equality. The essays are, as a whole, historically sophisticated and readable. Most essays are well researched, activate the imagination and, even for this seasoned scholar, deepen knowledge of the time. Moreover, although the book has no overt political agenda, only a peculiarly insensitive reader will miss the similarity between the issues that concerned some of the essays’ protagonists - the maldistribution of wealth, for example-and those of today. 
But is the book really about "Founders," as the title suggests? That term generally refers to the delegates at the Federal Convention and a few other contributors to revolutionary constitutionalism such as John Adams and Thomas Jefferson, whose public service took them out of the country in 1787. It can arguably include the champions of independence, the creators of the first state constitutions, and participants in the ratification debates. In any case, "Founders" had some role in the creation of the American republic and government under written constitutions. Perhaps that connection with institutional transformations is why references to the "Founders" and, even more, the "founding period" at first suggested a leaning toward the right among those who used those terms: they traveled comfortably with a defense of "traditional American history" - history, that is, before women's or black or social or cultural history made their appearance; history with politics and government as its core.

The characters in this book were not "Founders" in that sense or, if they were, their institutional contributions are not what the book explores. George Wythe, for example, was a delegate to the federal Convention and a leading figure in the Virginia ratifying convention; here he appears because of his views on race and slavery. Samuel Thompson was a passionate, outspoken critic of the Constitution at the Massachusetts ratifying convention (and a man whom some considered a bit unhinged later in 1788). Here he appears in an essay by T. H. Breen as the leader of a somewhat scary group of Maine insurgents who provoked a British naval bombardment that destroyed the town of Falmouth in 1775.

Some of the "revolutionaries" in Revolutionary Founders opposed the American Revolution. Colin G. Calloway’s useful essay, “Declaring Independence and Rebuilding 
a Nation: Dragging Canoe and the Chicamauga Revolution,” tells the story of an Indian who, in May of 1776, denounced the ruling Cherokee elders and launched a revolution to “rebuild an independent Cherokee nation based on militant defense of their land and sovereignty rather than accommodation to colonial pressures” (p. 191). That secessionist movement split, the Cherokees, and so weakened their military strength, but Dragging Canoe went on to form a multitribal confederation to fight the Americans. His “Chicamauga Revolution” continued after the Treaty of Paris (1783) and even survived Dragging Canoe’s death in 1792, but it ended disastrously with the Battle of Fallen Timbers (1794).

Similarly, the essay by Cassandra Pybus focuses upon black Loyalists and Methodists who ended up in Sierre Leone, where the ruling company rejected their demand for political participation and, in 1800, “ruthlessly suppressed” a rebellion challenging the company’s right to rule (167). Pybus' story, like Maya Jasanoff's recent Liberty’s Exiles: American Loyalists in A Revolutionary World (2011), reveals how even Loyalist exiles had absorbed the political message of the American Revolution and carried it to distant parts of the earth. Her protagonists might have been rebels, but their suppression, like that of the Chicamugas, kept them from being, as the book’s introduction claims, “founders of a new nation” (p. 7).

What, then, ties together the essays in the book? One term, with variations, threads through the text like a mantra: “ordinary people” (pp. 5, 53, 68, 70, 223, 235, 240), “ordinary folks” (p. 47), “ordinary men” (p. 68), “ordinary farmers” (p. 138), “ordinary white Virginians” (p. 135), “ordinary Pennsylvanians” (p. 250), “ordinary citizens” (p. 341), “ordinary Americans” (p. 389). What made certain eighteenth-century 
people "ordinary” is, it seems, that they were "nonelite” (p. 340) or "common folk" (250); they "worked with their hands" (p. 47), were "little-known participants in the Revolution” of “modest background” (p. 169) or with “little fortune” (236), “everyday Americans” (p. 5), or, in the words of the revolutionary soldier Joseph Plum Martin, “little men” who are usually denied the praise and recognition given to "great men” (p. 395). Not all characters in the book fit those descriptions: some were in fact men or women with considerable wealth and social status. Nonetheless, Revolutionary Founders goes beyond the usual suspects—intensely studied men such as Washington, Jefferson, Madison, Hamilton, and Adams—-to examine persons drawn from the masses of white people, male and female, whose approval the Revolution needed, and to others-such as slaves and Indians—-whose actions influenced its success or failure. All of its subjects were, as the subtitle says, "Rebels, Radicals, and Reformers” in one way or another.

The further one gets into the book, however, the more inappropriate the word “ordinary” seems. Can a self-educated Irish immigrant (William Findley, one of two protagonists in an essay by Terry Bouton) who played a prominent role in Pennsylvania politics and later became a respected, longtime member of the House of Representatives (where he was known as the "Venerable Findley”) be called “ordinary”? Or Abigail Adams, investor extraordinary in government bonds, who, as Woody Holton shows, succeeded in writing her own will, determining how her property would be distributed after her death, despite the law of couverture? Or Phyllis Wheatley, a Boston domestic slave who, as David Waldstreicher explains in an especially informative essay, won both freedom and a certain fame by writing poetry? Or Thomas Greenleaf, a New York newspaper publisher and ardent defender of the freedom of the press whose story Jeffrey 
Pasley tells? Or Thomas Paine, the subject of a lively essay by Jill Lepore? At first a poor English stay-maker and excise man, Paine became one of the eighteenth century's most important pamphleteers. All of these and others in the book were, as Sheila Skemp says of Judith Sargent Murray, an early and ardent defender of women’s rights, “truly extraordinary” (p. 289).

Revolutionary Founders' focus on a broad range of such notable but unfamiliar people is one of the book’s major strengths: it shows how the Revolution worked and what it meant in a grounded way, for specific people in different contexts. Moreover, many essays are by established scholars who reworked material they had already used in previously published books and who present their insights here through the experiences of individuals, which is a particularly user-friendly way of conveying historical information. Those characteristics make several essays well suited for assignment in courses where it's impossible to assign whole monographs, and where substantive short essays can complement, deepen, and sometimes bring into question standard textbook accounts.

A unit on the development of independence would, for example, benefit from Alfred Young’s “Ebenezer Mackintosh: Boston’s Captain General of the Liberty Tree”; Gary Nash’s “Philadelphia’s Radical Caucus That Propelled Pennsylvania to Independence and Democracy”; or, above all, Ray Raphael’s extremely teachable “Blacksmith Timothy Bigelow and the Massachusetts Revolution of 1774,” with its nutsand-bolts account of how resistance was organized in the Massachusetts countryside. Philip Mead’s essay on Joseph Plumb Martin gives a view of the Revolutionary War from the perspective of a soldier in the Continental Army that is short on patriotic hoopla 
but long on grime and hunger. Mead's essay also reminds us that, even in the eighteenth century, downward mobility happened: Martin’s father was a Yale graduate and so had a status his son never achieved. Michael A. McDonnell’s essay examines the discontent of tenant farmers and other poor militiamen in wartime Virginia, where regressive poll taxes, massive salary differentials between officers and regular soldiers, and other inequitable practices provoked an uprising in Loudon County in early 1776. Five years later, riots by disgruntled militiamen disrupted Virginia's defense forces just as the British army invaded the state. Calloway's essay on the Cherokees and James Kirby Martin’s on two “Forgotten Heroes of the Revolution” who were from the Oneida Nation provide snapshots of the war from the Indians’ perspectives.

Gregory Nobles and Terry Bouton contributed accounts of what are usually called Shays' Rebellion and the Whiskey Rebellion. Both of those names, the authors argue, are misnomers. Neither Daniel Shays nor Job Shattuck, who is sometimes portrayed as Shays’ second-in-command, led the insurrections in Massachusetts (though Shays did lead one contingent of insurgents in the critical fight at the Springfield Armory), nor did they even work together. Much like Raphael in an earlier essay, Nobles says "no one needed instructions from some central command to know what to do” (p. 223). The uprising of 1786-87 was local, “energized, if not directly organized, by people coming together in town meetings and county conventions, discussing their grievances, and reaching the mutual conclusion that they had to take direct action in their immediate region” (p. 222). The Massachusetts insurgents considered themselves part of a “regulation” (p. 222), like those earlier in the Carolinas, which sought to make an oppressive government more responsive to the people’s needs. Moreover, although 
support for the uprising was strongest in western parts of the state, it did not follow a neat “east-west, creditor-debtor” divide (p. 223). In short, the "insurrections . . . in Massachusetts” (note the plural) "seem to have stemmed not only from individual deprivation and deeply felt economic grievances, .. . but also from pre-existing standards of communal sentiment and solidarity, which played out differently from one town to the next” (p. 223).

Bouton makes a somewhat similar argument for the "Whiskey Rebellion,” a name, he says, that its enemies pinned on the uprising in an effort to belittle it (p. 249). Bouton raises an important issue: "In a republic, how far could ordinary people go to oppose government policies they saw as oppressive?” (p. 233) The repression of western Pennsylvania’s insurgents in 1794 served, he argues, to confine popular control of government to the polling place, which was less threatening to “elite interests.” (250) Unfortunately, Bouton's essay is one of the most thinly cited in the book. It leaves paragraph after paragraph with accounts of events, assertions about insurgents’ views, number, and identity, physical descriptions of individuals, and several direct quotations with no identified sources. Unlike Nobles’ careful attention to the complex considerations that lay behind the uprisings in Massachusetts, Bouton presents a stark picture of oppressed democrats rising against both state and national policies that were designed to benefit a social and financial elite. Within Pennsylvania, he says, "policy after policy" during the 1780 s “seemed to punish ordinary people to bolster the power of the elite”-eliminating paper money and low-cost government loans, chartering a bank for the benefit of wealthy merchants, raising taxes collected in gold and silver to pay off a Revolutionary War debt held by rich speculators (p. 237). Alexander Hamilton’s 
financial plans "magnified the problems inherent in state policies," paying off the war debt at face value to speculators who bought it "at pennies on the dollar" and paying for that boon to the favored few with "new taxes" (p. 238).

There is good reason to suspect that the story of democracy in revolutionary Pennsylvania , particularly in the 1780s, was more complicated that Bouton suggests. Owen Ireland, for example, argues that the "Constitutionalist” Party of William Findley (which defended the state's democratic constitution of 1776 against its "Republican" critics and controlled the state for the first decade after independence) clung to wartime Test Acts that, by requiring loyalty oaths, excluded Quakers, Anglicans, Lutherans, and some other non-Calvinist sectarians from voting. When the Test Acts were finally modified and then repealed in the mid-1780s, those new voters gave the Republicans who had supported their re-enfranchisement—and were led by Bouton’s oppressive elite—a firm numerical majority. ${ }^{1}$ Who, then, were the champions of democracy? More important, Bouton’s description of Hamilton’s financial politics ignores the groundbreaking scholarship of Max Edling, who showed that Hamilton's assumption of state debts led to the abolition of those oppressive state direct taxes that caused so much popular discontent in the 1780s. By funding the debt Hamilton was able to reestablish the credit of the United States without immediately paying off the principal (though the value of shares in the debt of course rose). He needed only to pay reliably the (reduced) interest on it, which he did with import duties and a few excise taxes, including one on distilled liquor. The whiskey tax, which was levied on stills and so on producers, not, like the modern liquor tax, on consumers, provoked serious discontent in western Pennsylvania and some other states, but Hamilton’s policies gave most “ordinary 
Americans" a tax break and pacified much of the countryside. ${ }^{2}$ In 1796 , William Findley claimed that the Pennsylvania insurgents had opposed the tax on whiskey, not the funding system, and questioned the wisdom of "forcible opposition to government," which Bouton condemns as a "self-serving” rewriting of history (248-49). It is possible, however, that the Congressman, who was delightfully ready to rethink old convictions, had simply arrived at a more capacious understanding of “ordinary Americans”” best interests in the new nation.

T. H. Breen's essay, which is again thin on citations (in part because Samuel Thompson's personal papers were destroyed in the early nineteenth century), also offers an interpretation of “Thompson’s War” in Maine that turns in part on class tensions. Breen sees Thompson as motivated by hostility toward both the British and the "Falmouth gentry,” who, in turn, supposedly feared that unbridled insurgents like Thompson would "destabilize the traditional order of society” (p. 63). The evidence Breen offers indicates, however, that the leaders of Falmouth were concerned instead for the town's physical safety, and they had good reason to fear "that if any number of men at any time, and in any manner, may collect together and attack any thing, or any person they please, every body may be in danger” (p. 63). “Thompson’s War” ultimately proved more destructive to his countrymen, rich and poor, than to the British, which is one reason the establishment of regular government capable of controlling ad hoc local insurgencies became so important in 1775 and 1776 (and later).

Sixty years ago Irving Brant published an article on James Madison and the separation of church and state that I have always assigned in my course on the American Revolution. ${ }^{3}$ Jon Butler’s solid essay on “James Ireland, John Leland, John 'Swearing 
Jack’ Waller, and the Baptist Campaign for Religious Freedom in Revolutionary Virginia” examines much the same subject from the perspective of those Baptists whose massive petitions made passage of the landmark Virginia Statute of Religious Freedom (1786) possible. It would be wonderful to assign the essay along with the Statute, which Jefferson wrote and Madison saw through the Virginia legislature. Students might then understand why a law that, in effect, opened the way toward the modern secular state began by citing "Almighty God" who "made the mind free," and how both Enlightenment principles and profound religious belief contributed to what Jefferson would call the separation of church and state in the United States.

The Revolution also produced a new questioning of slavery's legitimacy. Richard S. Newman's essay skillfully describes how three free blacks—Prince Hall, Richard Allen, and Daniel Coker—fought racial injustice and helped build a "communal infrastructure" such as Masonic lodges and churches "that would guide black life beyond bondage” (p. 306). Melvin Patrick Ely’s essay on "Richard and Judith Randolph, St. George Tucker, George Wythe, Syphax Brown, and Hercules White: Racial Equality and the Snares of Prejudice” is, however, among the most thought-provoking in the book. In 1796 Richard Randolph, a member of one of the state’s most illustrious families, wrote a will that included a "blistering attack on slavery" (p. 323), provided for the emancipation of the slaves he had inherited, and allocated to them land from his estate so they could support themselves as free men. Since those slaves were mortgaged to creditors, it took some fifteen years before his wife, Judith, the heroine of Ely's story, could fulfill his wishes. Then she promptly bought a few more slaves as household servants. 
St. George Tucker, who influenced Randolph, wrote a dissertation proposing a scheme of gradual emancipation for Virginia, but noted that deep-seated prejudice would obstruct its adoption. Nonetheless, two of Randolph’s emancipated slaves, Syphax Brown and Hercules White, prospered and even received justice against white men in the courts. And on "Israel Hill," the slave lands carved from the Randolph estate, free black men sometimes "settled down with white wives" and one family even moved west with a group of whites (p. 334). Many more ex-slaves and their descendants stayed put, allowing the black community there to survive on into the twentieth century. This complex, human story reveals both the possibilities and limits of revolutionary antislavery, destroys simplisticl assumptions about a monolithic South, and helps explain why the Founders did not, and probably could not, simply end American slavery.

The book also includes arresting accounts of demands for political, social, and even economic equality as early as the 1770 s. Nash quotes a set of Pennsylvania military associators who asserted in June 1776 that "great and over-grown rich men” should not be trusted with seats in the upcoming revolutionary convention; the only qualifications were "honesty, common sense, and a plain understanding . . . unbiased by sinister motives” (p. 78). Similarly, a half century later Andrew Jackson insisted that any reasonably intelligent men could exercise the powers of government. “Jacksonian democracy” was a revolutionary product, like Jackson himself, the last president to have fought in the Revolution. Pennsylvania radicals also wanted, but failed, to get a provision in their state constitution limiting the ownership of private property (p. 80). A decade later, Terry Bouton reports, Pennsylvanians like William Findley feared that “wealthy men might use their affluence to buy power and subvert the republic_-just as 
they had done to Greek and Roman republics.” Americans, Findley insisted, had not fought the Revolution to advance "principles of united avarice" or allow the rich to “engross all the wealth, power, and influence of the state” (p. 236).

Again in the 1790s, Robert Coram, a Wilmington, Delaware, radical described in Seth Cotlar’s essay on “the American Revolution’s Legacy of Economic Populism,” warred against the increasing disparity of wealth in the new republic, which looked to him, Cotlar says, "like a repudiation of the Revolution for which he had risked his life" (p. 340). For centuries, Coram wrote, humans had “created 'an artificial inequality among themselves and then cr[ied] out it is all natural.'” A democratic government should establish a more "rational" distribution of property (p. 347) and also a system of universal education, which he thought would promote equality. There he was like Jedediah Peck, the subject of an essay by Alan Taylor. Peck advocated state funding for schools so "improvement" would be, as he put it, "within the reach and power of the humblest citizen” (p. 385). Coram's readiness to question "the right to exclusive property," like the views of the utopian radical Herman Husband, on whom Wythe Holt wrote and who advocated a redistribution of land so nobody had either nothing or more than 2,000 acres, were extreme at the time (p. 253). There is nonetheless a ring of familiarity in Coram's lament about living in a world where, as Cotlar put it, "a few were becoming splendidly wealthy and comfortable while the majority lived perpetually on the edge of economic ruin” (p. 340).

In his “Afterword," Eric Foner says that "one of the most enduring results of the struggle for independence" was "an upsurge of egalitarian sentiment that threw into question not only monarchical rule but inequalities of every sort. This," he says, "was the 
essence of the American Revolution.” That downplaying of the political ("not only monarchical rule but ...”) is hardly unique to Foner, but it is essentially ahistorical. Were the establishment of the world's first modern republic and the enactment of its first written constitutions less essential to the Revolution than the social changes that were inspired by 1776 but took longer to realize--- or that have proven enduringly elusive?. The creation of a durable republic might seem unexciting today, when the world is full of republics, but that was not the case in the eighteenth century. Men like Washington and Madison worried about popular disorder in the 1780s in good part not because it threatened them personally, but because it had heralded the end of republics throughout previous history and so threatened to undermine the Revolution's central achievement. For Thomas Paine, no slouch when it came to the rights of women or the evils of slavery, the significance of the American Revolution turned on the transformation it brought "in the principles and practice of governments.” 4 As late as 1828, Noah Webster's dictionary defined the word "revolution" as "a material or entire change in the constitution of government."5 But the creation of a government that depended on popular consent, affirmed the existence of popular rights, and was traditionally connected with social equality led almost inevitably to campaigns against privilege.

To discount institutional change while emphasizing movements for social and economic equality, in short, is a mistake: political transformations and social change were parts of one story. Essay after essay in Revolutionary Founders affirms that point. The book also reminds us that the actors in the American Revolution were not confined to a handful of familiar names, but included women as well as men, blacks as well as whites, 
Indians as well as European-Americans. It tells that rich story in complex detail, essay by essay, through one extraordinary person after another.

Pauline Maier is the William Rand Kenan, Jr., Professor of American History at MIT. Her most recent book is Ratification: The People Debate the Constitution, 1787-1788 (2010).

1. Owen S. Ireland, “The Crux of Politics: Religion and Party in Pennsylvania, 1778-1789,” William and Mary Quarterly 42 (1985): 453-75; “The People’s Triumph: The Federalist Majority in Pennsylvania, 1787-1788,” Pennsylvania History 56 (1989): 93-113; “The Invention of American Democracy: The Pennsylvania Federalists and the New Republic,” Pennsylvania History, 67 (2000): 161-71, and Religion, Ethnicity, and Politics: Ratifying the Constitution in Pennsylvania (1995), esp. xvi-xviii, 217-53.

2. Max Edling, A Revolution in Favor of Government: Origins of the U.S.

Constitution and the Making of the American State (2003), 157-59, 191, 207-9, 211-12;

Max Edling and Mark D. Kaplanoff, “Alexander Hamilton’s Fiscal Reform:

Transforming the Structures of Taxation in the Early Republic,” William and Mary Quarterly 61 (2004): 713-44.

3. Irving Brant, "Madison: On the Separation of Church and State," William and Mary Quarterly 3 (1951): 3-24.

4. Thomas Paine, The Rights of Man, Part the Second (1792) available at http://www.constitution.org/tp/rightsman2.htm. Accessed September 2, 2011. The quotation appears in the fourth paragraph of the introduction. 
5. Definition from Noah Webster, American Dictionary of the English Language (1828), available at http://1828.mshaffer.com/d/search/word,revolution. Accessed October 28, 2011. 